\title{
Michał Gałędek
}

Uniwersytet Gdański e-mail: michal.galedek@wp.pl

telefon: +48585232917

DOI: 10.15290/mhi.2014.13.01.05

\section{System rekrutacji wykwalifikowanych kadr urzędniczych w konstytucyjnym Królestwie Polskim}

\begin{abstract}
SUMMARY
Recruitment of Skilled Officials in the Constitutional Kingdom of Poland (1850-1830)

The aim of the article is to explain the legal terms of the recruitment for administrative offices introduced in the Kingdom of Poland. The implementation of this system was a basic condition to organize a fully professional administrative staff professionally prepared to perform its duties. Based on formal and dogmatic method the publication analyses the regulations of the namestnik's (governor's) Decree of November 12, 1816, concerning examination boards in the Kingdom of Poland. The author generally omitted issues associated with its implementation. Thus the article presented the ideas of Polish governmental elites at the beginning of the 19th century. Any observations were confronted with the contents of the earlier Decree of April 29, 1808, which established examination boards in the Duchy of Warsaw. The author tries to prove that this system of recruitment was the prototype and the main point of reference for the system of the Kingdom of Poland.
\end{abstract}

Key words: recruitment of officials, administration, bureaucracy, examination, commission, Congress Poland

Słowa kluczowe: rekrutacja kadr urzędniczych, administracja, biurokracja, egzaminy, komisja, Królestwo Polskie

W utworzonym w 1815 roku konstytucyjnym Królestwie Polskim, mimo wielu odrębności, głównie jednak formalnych, często tylko symbolicznych (jak w przypadku zastąpienia jednoosobowych organów administracyjnych przez kolegialne), kontynuowana była podstawowa linia rozwoju ustrojowego, wyznaczona przez wzorce napoleońskiego Księstwa Warszawskiego'. Względem aparatu administracyjnego zasadniczo utrzymane zostały wszystkie mechanizmy właściwe dla systemu biurokratycznego, w jego wczesnej, ściśle scentralizowanej postaci, wywodzącej się z systemu ukształtowanego w państwach

1 H. Izdebski, Rada Administracyjna Królestwa Polskiego 1815-1830, Warszawa 1978, s. 15-16. 
absolutnych, twórczo przeobrażonego przez Napoleona i w tej formie upowszechnionego $\mathrm{w}$ całej niemalże kontynentalnej Europie $\mathrm{w}$ pierwszej połowie XIX wieku².

Jednym z podstawowych wyznaczników systemu biurokratycznego była zawodowość kadr urzędniczych ${ }^{3}$. Wymagała ona stworzenia mechanizmów instytucjonalnych zapewniających dopływ wykwalifikowanych sił do kompetentnego i sprawnego zarządzania państwem ${ }^{4}$. Aby zrealizować ten cel, najpierw w Księstwie Warszawskim, a następnie w Królestwie Polskim, przyjęto dość ambitny model rekrutacji kadr urzędniczych, wedle którego powołanie na urząd (tak administracyjny, jak i sądowy) uzależnione było od spełnienia trzech warunków decydujących o uznaniu, że urzędnik jest fachowo przygotowany do wykonywania powierzonej mu pracy: wykształcenia, doświadczenia w służbie państwowej oraz zaliczenia państwowego egzaminu przed urzędniczą komisją egzaminacyjną ${ }^{5}$. Względem zaś osób aspirujących do objęcia wyższych posad w administracji (należących do III klasy) wymagania te zostały szczególnie rozbudowane. Oprócz wyższego wykształcenia niezbędne było bowiem odbycie dwóch praktyk i zaliczenie dwóch egzaminów.

\section{Geneza}

System rekrutacji fachowych kadr urzędniczych oparty na tych zasadach wprowadzony został w Księstwie Warszawskim mocą dekretu z 29 kwietnia 1808 roku $^{6}$. Przyjęto model podobny do rozwiązań funkcjonujących w Austrii

2 Szerzej zob. M. Gałędek, Rola administracji w systemie politycznym Królestwa Polskiego do 1830 r., [w:] System polityczny, prawo, konstytucja i ustrój Królestwa Polskiego 1815-1830, Radzymin 2013, s. 133-139, 152-153; H. Izdebski, Historia administracji a historia biurokracji, „Państwo i Prawo” 1975, z. 5, s. 64-70; por. też: M. Gałędek, Ustawa konstytucyjna Królestwa Polskiego w poglądach księcia Franciszka Ksawerego Druckiego-Lubeckiego, [w:] System polityczny..., s. 289-290. Na temat silnej niechęci do tworzenia zawodowej biurokracji w kręgach konserwatywnych elit Królestwa Polskiego zob. M. Mycielski, Rząd Królestwa Polskiego wobec sejmików i zgromadzeń gminnych 1815-1830, Warszawa 2010, s. 35-38, 49; idem, „Miasto ma mieszkańców, wieś obywateli”. Kajetana Koźmiana koncepcje wspólnoty politycznej (do 1830 roku), Wrocław 2004, s. 131-133.

3 H. Izdebski, Historia administracji, Warszawa 1997, s. 37.

4 O kształtowaniu się systemów szkoleniowo-rekrutacyjnych jako części procesu profesjonalizacji biurokracji, poczynając od XVIII w., zob. ogólnie: J. C. N. Raadschelders, Handbook of Administrative History, New Brunswick 1998, s. 151-153, 156-157, 161. Zauważa on m.in.: „Up to the early-eigteenth century public servants could be recruited on the basis of volunteer experience and informal relations. From then on it became normal that one had to apply for an office and prove ability" - ibidem, s. 156; por. na przykład omówienie procesu uzawodowienia administracji w Wielkiej Brytanii: N. Chester, The English Administrative System: 1780-1870, Oxford 1981, s. 282-321.

5 J. Malec, Wpływy napoleońskie w strukturze administracji ziem polskich w pierwszej połowie XIX wieku, [w:] Studia z dziejów administracji nowożytnej, red. J. Malec, Kraków 2003, s. 118-119.

6 O dyskusji na temat wprowadzenia „istotnie kwalifikowanej służby administracyjnej” w Księstwie Warszawskim zob. M. Krzymkowski, Status prawny urzędników Księstwa Warszawskiego, Po- 
i w Prusach7. W obu tych państwach również powołano do życia komisje egzaminacyjne o podobnym charakterze i zasadach działania ${ }^{8}$. Natomiast trudno w przyjętych zasadach doszukiwać się bezpośrednich inspiracji francuskich ${ }^{9}$.

Projekt ustanowienia komisji egzaminacyjnych wniósł pod obrady Rady Stanu 19 lutego 1808 roku minister spraw wewnętrznych, Jan Łuszczewski (występujący zapewne jako minister właściwy do podjęcia inicjatywy w zakresie tej problematyki), „przyznając referendarzowi Karolowi Woydzie udział podanych myśli do tego projektu"10. Istotny udział w opracowaniu systemu rekrutacyjnego dla urzędników Księstwa Warszawskiego mieli także Stanisław Potocki i Stanisław Staszic ${ }^{11}$. Szczególnie ten ostatni aktywnie angażował się również

znań 2004; P. Cichoń, Rozwój myśli administracyjnej w Księstwie Warszawskim 1807-1815, Warszawa 2006, s. 58-64; idem, Korpus urzędniczy w myśli administracyjnej Księstwa Warszawskiego 1807-1815, [w:] Krakowskie Studia z Historii Państwa i Prawa, red. W. Uruszczak, D. Malec, Kraków 2007, s. 147-171; idem, Kwalifikacje zawodowe urzędników jako podstawa kształtowania się systemu biurokratycznego w Księstwie Warszawskim, [w:] Dzieje biurokracji na ziemiach polskich, red. A. Górak, I. Łuć, D. Magier, t. 1, Lublin - Siedlce 2008, s. 133-146; B. Leśnodorski, Szkoła Prawa i Nauk Administracyjnych w Księstwie Warszawskim, [w:] Studia z dziejów Wydziału Prawa Uniwersytetu Warszawskiego, Warszawa 1963, s. 18.

7 W Prusach państwowe egzaminy na posady w sądownictwie organizowano od 1755 r., zaś w administracji od 1770. Te ostatnie musiały być złożone przed Wyższą Komisją Egzaminacyjną (Oberexaminationskommission). W początkach XIX w. system egzaminacyjny był reformowany dwukrotnie - w 1806 i w 1817 r. Na temat rozwiązań obowiązujących w Prusach i niektórych innych państwach niemieckich („The development in Prussia exemplifies for the general trend” in Germany) w pierwszych dekadach XIX w. zob. M. Stolleis, Public Law in Germany, 1800-1914, Oxford 2001, s. 209-213; por. D. F. Lindenfeld, The Practical Imagination. The German Sciences of States in the Nineteenth Century, Chicago 1997, s. 36, 51-55, 62-64, 67-74; K. H. Osterloh, Joseph von Sonnenfels und die österreichische Reformbewegung im Zeitalter des aufgeklärten Absolutismus: Eine Studie zum Zusammenhang von Kameralwissenschaft und Verwaltungspraxis, "Historische Studien” nr 409, Lubeka 1970, s. 243-263; M. Rowe, From Reich to State. The Rhineland in the Revolutionary Age, 1780-1830, Cambridge 2003, s. 133-137, 255-256 (o napoleońskim systemie edukacyjno-rekrutacyjnym i o wdrożeniu pruskiego modelu w Nadrenii).

8 Według Adama Winiarza system egzaminów przeprowadzanych przez komisje został w Księstwie do pewnego stopnia zintegrowany z równolegle rozwijającym się szkolnictwem, co podówczas było rozwiązaniem oryginalnie polskim. Komisje egzaminacyjne miały stanowić bowiem ostatnie ogniwo systemu edukacyjnego, A. Winiarz, Organizacja i działalność komisji egzaminacyjnych w Księstwie Warszawskim i Królestwie Polskim (1807-1831), „Przegląd Historyczno-Oświatowy” 1986, nr 4, s. 447. Jeżeli rozumieć tę konstatację w ten sposób, że ukończenie pewnego etapu edukacji stanowiło warunek sine qua non przystąpienia do egzaminu przed urzędniczą komisją egzaminacyjną, to to samo rozwiązanie wyróżniające podówczas model polski znalazło zastosowanie również w Królestwie.

9 Fakt ten koresponduje z podkreślaną w literaturze powierzchowną tylko recepcją administracyjnych rozwiązań napoleońskich i związanym z tym licznym odwoływaniem się do rozwiązań pruskich i austriackich, zob. M. Kallas, Organy administracji terytorialnej w Księstwie Warszawskim, Wrocław 1975, s. 151-162; P. Cichoń, Wpływy francuskie w administracji Księstwa Warszawskiego, „Zeszyty Naukowe Uniwersytetu Jagiellońskiego. Prace Historyczne” 2013, nr 140, z. 1, s. 17.

10 Protokoły Rady Stanu Księstwa Warszawskiego, t. 1, cz. 1, wyd. B. Pawłowski, Poznań 1960, s. 159.

11 Zdaniem Kajetana Koźmiana, „Staszic zasiadając w Dyrekcji Edukacyjnej pod gorliwym jej prezesem Stanisławem Potockim był najczynniejszym jego doradcą i pomocnikiem" - K. Koźmian, Pamiętniki, t. 2, Wrocław 1972, s. 183). Należy jednak zwrócić uwagę, że ani S. Potocki, ani też S. Staszic, którzy według ustaleń A. Winiarza (A. Winiarz, op. cit., s. 446-447) zajmowali się projektem 
w przygotowanie analogicznych rozwiązań w Królestwie Polskim, a następnie przewodniczył Najwyższej Komisji Egzaminacyjnej².

System wypracowany w toku przedstawionych powyżej prac stanowił swoistą kontrpropozycję dla alternatywnej koncepcji lansowanej jeszcze w okresie istnienia Komisji Rządzącej w 1807 roku przez Feliksa Łubieńskiego. Szef resortu sprawiedliwości dążył do stworzenia szkoły prawa i administracji przygotowującej tak teoretycznie, jak i praktycznie do wykonywania zawodów w szeroko rozumianej służbie publicznej. Samo ukończenie szkoły prawa (dla zatrudnienia w wymiarze sprawiedliwości) bądź administracji (dla kariery urzędniczej) byłoby wystarczające dla objęcia posady w służbie publicznej ${ }^{13}$. Propozycja F. Łubieńskiego została jednak odrzucona ze względu na brak środków finansowych na ten cel, a rok później przyjęto rozwiązanie zgłoszone przez Potockiego ${ }^{14}$.

Natomiast w Królestwie Polskim prace nad przygotowaniem stosownego aktu prawnego wdrażającego system przyjmowania do administracji państwowej fachowej kadry urzędniczej zostały podjęte stosunkowo szybko. Kwestia ta stała się najpierw przedmiotem zainteresowania tzw. Komitetu Organizacyjnego Cywilnego, działającego w latach 1814-1815. O chęci utrzymania dotychczasowego systemu (i to pomimo przeświadczenia, iż w Komitecie dominowali konserwatyści niechętni rozbudowywaniu i profesjonalizacji struktur biurokratycznych według modelu stworzonego w Księstwie Warszawskim oraz opowiadający się za powrotem rozwiązań przedrozbiorowych) w "Zasadach do zaprowadzenia Nowych Magistratur Administracyjnych w kraju X.a W.go postanowionych", przyjętych na sesji Komitetu 24 stycznia 1815 roku zamierzano m.in. ustalić zasadę, iż „Ci, którzy w żadnej służbie publicznej nie byli, wtenczas tylko do kandydacji i wyboru dopuszczonymi będą, gdy wiary-

o komisjach egzaminacyjnych na wstępnym etapie, w świetle treści protokołów Rady Stanu nie brali udziału w pracach nad tą ustawą na tym etapie jej przygotowywania. Brakuje też jakichkolwiek informacji o aktywności w tej materii K. Woydy na forum Rady. Pojawia się za to adnotacja, że na żądanie J. Łuszczewskiego projekt dekretu o komisjach egzaminacyjnych oddano 29 marca do referatu J. Morawskiego, a zatem odebrano go K. Woydzie, który, jak można domniemywać, po 12 lutego żadnych nowych "myśli do projektu” nie zaprezentował. Z sesji odbytej tego dnia sporządzono referat odczytany właśnie przez J. Morawskiego na posiedzeniu 6 kwietnia, podczas której był on jeszcze "roztrząsany i na nowo zredagowany", a następnie 19 kwietnia poddany "ostatniej deliberacji" (Protokoty Rady Stanu..., s. 224, 236, 255-256). Natomiast nie odnajdujemy w protokołach żadnej wzmianki jakoby - jak podaje A. Winiarz - to na wniosek S. Staszica Rada Stanu na sesji 19 kwietnia podała wytyczne do opracowania projektu ustanowienia komisji egzaminacyjnych, zob. A. Winiarz, Stanisława Staszica koncepcja organizacji szkolnictwa w teorii i praktyce, „Rozprawy z Dziejów Oświaty" 2006, t. 54, s. 68.

12 Na temat Staszicowskiej centralistycznej i etatystycznej wizji administracji, w którą wpisane było zapotrzebowanie na wszechstronnie wyedukowanych urzędników, patrz zwłaszcza: K. Koźmian, op. cit., s. 215-216.

13 B. Leśnodorski, op. cit., s. 18; A. Winiarz, Organizacja..., s. 446.

14 Por. A. Winiarz, Organizacja..., s. 446-447. 
godnymi atestami skończone zupełnie nauki szkolne i odbyty z nauki do żądanego urzędu lub funkcji potrzebnej oraz znajomości praw i urządzeń krajowych w akademii i przed komisją egzaminacyjną rządową egzamin udowodnią"15.

Dorobek Komitetu nie został bezpośrednio wykorzystany przy organizacji systemu administracyjnego Królestwa Polskiego. W tej sytuacji pierwszy projekt „względem prawideł w przyjmowaniu do biur rządowych młodzieży ze szkół wychodzącej” prezydującego w Wydziale Oświecenia Narodowego i Spraw Wyznań Religijnych został przesłany Radzie Stanu 11 listopada 1815 roku $^{16}$. Nie udało się ustalić, czy akt ten rzeczywiście wszedł w życie tymczasowo regulując stosunki w tym zakresie przez następny rok. W każdym razie projekt sygnowany przez S. Staszica miał jedynie na celu uregulowanie zasad obsadzania niższych stanowisk w administracji, „zważając, że przyjmowanie do kancelarii i funkcji publicznych młodzieży za wcześnie ze szkół wychodzącej szkodliwym jest tak dla niej samej, jako też dla kraju potrzebującego do usług swoich należycie usposobionych ludzi". Dokument pomijał kwestie nominacji na wyższe urzędy, być może z tego względu, że nieuregulowany był jeszcze status warszawskiej uczelni wyższej, a tym samym i roli, jaką miała ona odgrywać w systemie edukacji i rekrutacji kadr urzędniczych. W rezultacie ustalono tylko, że „młodzież wychodząca ze szkół nie ma być przyjmowana ani do kancelarii i biur jakichkolwiek władz rządowych, ani do funkcji publicznych, dopóki nie złoży zaświadczeń szkolnych okazujących dobre obyczaje, klasę skończonych nauk, toż zezwolenie rodziców lub opiekunów". Przede wszystkim jednak wspominano o chęci kontynuowania systemu egzaminacyjnego przy przyjmowaniu do służby, stanowiąc, iż „młodzieniec mający zaświadczenia z należycie ukończonych nauk klasy 6tej może być uzdatniony na oficjalistę tak biura, jako też kancelarii i przypuszczony do egzaminu departamentowego”. Z kolei „młodzieniec mający zaświadczenia z należycie ukończonej szkoły wydziałowej lub czwartej klasy szkoły departamentowej może być przyjęty na kancelistę lub oficjalistę podręcznego" bez konieczności zdawania egzaminu ${ }^{17}$.

Prace nad finalną wersją systemu rekrutacji na posady w zarządzie państwowym rozpoczęły się kilka miesięcy później. W pierwszej połowie 1816 roku namiestnik Józef Zajączek powołał bowiem deputację, której celem było przygotowanie projektu ustalającego warunki obsadzania urzędów admini-

15 Biblioteka im. Czartoryskich w Krakowie, sygn. 5236, k. 115 (art. 44 projektu); por. J. Przygodzki, Rada Najwyższa Tymczasowa Księstwa Warszawskiego 1813-1815: organizacja i działalność, Wrocław 2002, s. 188-189; zob. też wcześniejszy projekt w tej materii Wolickiego przedstawiony na sesji 12 września 1814 r. - Biblioteka im. Czartoryskich w Krakowie, sygn. 5233, k. 141-142

16 Archiwum Główne Akt Dawnych w Warszawie (AGAD), akta I Rady Stanu Królestwa Polskiego (I RS KP), sygn. 67, k. 1.

17 Ibidem, k. 2-3. 
stracyjnych $^{18}$. Niewiele niestety wiemy o jej działalności. W aktach pojawia się jedynie informacja, że 7 lipca namiestnik przesłał Radzie Stanu „projekt do uchwały tyczący się egzaminów", stanowiący zapewne owoc prac deputacji ${ }^{19}$. Został on następnie powierzony referendarzowi stanu, Adamowi Prażmowskiemu, do rozpatrzenia i przygotowania na tej podstawie referatu. Prażmowski był jednak jednym z członków owej deputacji i powołując się na ten fakt nie zgłosił do projektu żadnych uwag merytorycznych. Stwierdził jedynie, że zaproponowane przez deputację „odwołanie się na samym wstępie do dekretu króla saskiego powinno by być opuszczonym"20. Wniosek ten został przyjęty i powyższe wyrażenie zostało wykreślone $z$ treści projektu ${ }^{21}$, jednakże jest ono godne odnotowania, gdyż potwierdza wprost, że głównym punktem odniesienia w pracach nad systemem rekrutacyjnym funkcjonującym w Królestwie Polskim był model obowiązujący w Księstwie Warszawskim, ustalony na podstawie dekretu z 29 kwietnia 1808 roku.

Po przeszło dwumiesięcznej przerwie, w czasie której Rada Stanu poświęciła swoją uwagę innym problemom, 20 września 1816 roku Ogólne Zgromadzenie wreszcie rozpatrzyło projekt całościowo i ostatecznie. Jego treść referował w imieniu deputacji S. Staszic, domniemany współtwórca kopiowanych rozwiązań z czasów Księstwa Warszawskiego ${ }^{22}$. Radcowie nie analizowali przedstawionego im systemu in corpore. Od razu przystąpili do szczegółowego rozbioru projektu, deliberując, artykuł po artykule, nad kolejnymi detalicznymi kwestiami i wprowadzając do przedstawionych regulacji zaledwie kilka stosunkowo drobnych poprawek ${ }^{23}$. Nikt nie zgłosił wątpliwości do żadnego

18 A. Winiarz, Organizacja..., s. 453.

19 AGAD, I RS KP, sygn. 67, k. 4.

20 Ibidem, k. 4.

21 Ibidem.

22 AGAD, I RS KP, sygn. 67, k. 18.

23 Rada Stanu wprowadziła do projektu deputacji następujące poprawki: „z wniosku ministra spraw wewnętrznych objaśniono wyraz «technologii» wytłumaczeniem przydanym «wiadomości praktyczne sztuk i rzemiosł». Wymazano z liczby wymienionych urzędów, do których mają być egzaminowani kandydaci, burgrabiów jako nieegzystujących w teraźniejszym składzie sądownictwa. Poprawiono wyraz "sędziowie obieralni», na ten inny: «kandydaci na sędziów obieralnych» przez wzgląd, że ich wybór dopiero od rady wojewódzkiej zależeć będzie. Zamiast: iż «Komisja Najwyższa Egzaminacyjna odbierać będzie co pół roku wyciągi protokołów od komisji wojewódzkich» zmieniono [na]: «po każdym odbytym egzaminie odbierać będzie od komisji wojewódzkich wyciągi z protokołu». Zgodzono się na wniosek ministra spraw wewnętrznych, aby między warunkami do egzaminu nie wymagać metryki chrztu i pomieniony warunek z projektu wymazanym został. Przez wzgląd, iż na chirurgów powiatowych szczególniej wiadomość chirurgii jest potrzebną, wyraz, iż powinien mieć przynajmniej stopień magistra medycyny zmieniono [na] stopień magistra chirurgii. Zgodzono się na ograniczenie tylko czasu trwać mającego posiedzenia egzaminacyjnego, bez wyrażenia liczby kandydatów, w tym przeciągu egzaminować się mogących. Co do podpisu świadectwa egzaminowanemu uznano, iż samego prezesa dostatecznym będzie, z powodu uwolnienia od podpisywania tych z członków, którzy by przeciwnego byli zdania. Przydano oraz, aby podpis prezesa był kontrasygnowany, czyli zaświadczony przez trzy- 
z podstawowych elementów zaproponowanego systemu, ani tym bardziej nie podważano potrzeby jego wprowadzenia jako takiego. Tak jak w Księstwie formalnie i merytorycznie potwierdzone kwalifikacje miały stać się podstawą rekrutacji kadr urzędniczych. Uwypuklono nawet ten fakt, dodając do projektu wymownie brzmiące postanowienie, „iż żadna z władz krajowych podawać nie może, ani mianować do miejsc wakujących, osób nieegzaminowanych podług powyższych przepisów i zaświadczenia zdolności niemających"24. Radcowie stanu, pomni zapewne doświadczeń z czasów Księstwa, w ten sposób starali się być może podkreślić, że wolą prawodawcy jest, aby w Królestwie nie czyniono już żadnych odstępstw od ustanowionych wymagań zawodowych.

W tej postaci projekt został zatwierdzony postanowieniem namiestnika z 12 listopada 1816 roku określanym mianem „postanowienia o egzaminach”25.

\section{Cele}

W nowo wydanym akcie prawnym zostały wyrażone expressis verbis dwa główne cele, które planowano osiągnąć zatrudniając w aparacie administracyjnym Królestwa wykwalifikowany korpus urzędniczy.

Po pierwsze - zgodnie $\mathrm{z}$ deklaracją prawodawcy - u źródeł tej decyzji stanęło pragnienie zabezpieczenia „rządu i obywateli od zawodnych wyborów” poprzez zapewnienie krajowi „publicznej służby na zaufaniu i na dowiedzionej zdatności ugruntowanej"26. Dwa zatem elementy miały przesądzać o prawidłowym doborze kadr urzędniczych: nie tylko „dowiedziona zdatność ugruntowana" zbadana właśnie w trakcie egzaminu, ale i "zaufanie”. Nie zostało wprawdzie dookreślone, czyim zaufaniem winni cieszyć się urzędnicy, jakkolwiek jednak konstrukcja całego wstępu pozwala domniemywać, że skoro to "rząd i obywatele" mieli być „zabezpieczeni od zawodnych wyborów”, to legitymizowany urzędnik winien być zaakceptowany zarówno przez władze, jak i przez „,czynnik społeczny"27.

mającego protokół członka. Objaśniono z powodu pokrewieństwa członka komisji egzaminacyjnej przydaniem wyrazu «w pierwszym lub drugim stopniu». Minister spraw wewnętrznych wnosił, iż można by z projektu wypuścić podawanie usposobionych egzaminowanych do wiadomości publiczności, dla oszczędzenia skromności wielu z nich, lecz dla uczynionej przez nas uwagi, iż to bodźcem będzie dla komisji do ściślejszego pilnowania się w wyrokowaniu o zdatności kandydatów, przepis ten utrzymany został. Wyjątek dla urzędujących teraz od egzaminu ograniczony [...] razem «do dnia publikacji niniejszego postanowienia»" - AGAD, I RS KP, sygn. 418, k. 375-377 (protokół z posiedzenia Rady Stanu Ogólnego Zgromadzenia 23 września 1816 r.).

Ibidem, k. 377.

25 Ibidem, sygn. 67, k. 19-23.

26 „Dziennik Praw Królestwa Polskiego”, t. 2, nr 10, s. 225.

27 Ibidem. 
Warto przy tym zwrócić uwagę, że kwestii zaufania nie podniesiono we wstępie do dekretu obowiązującego w Księstwie Warszawskim, w którym skupiono się jedynie na podkreśleniu korzyści, których oczekiwano po wdrożeniu systemu należytego przygotowywania kadr do wykonywania funkcji urzędniczych. Stwierdzano, że wydanie tych przepisów spowodowane było pragnieniem, aby ,jak najmocniej mieć dowody zdatności wszelkich urzędników publicznych" i przekonaniem, że "nie tylko uczciwy sposób myślenia, gorliwość w pełnieniu obowiązków, ale nadto, prawdziwie gruntowna nauka odpowiadająca powołaniu oraz doświadczenie i wprawność istotnie do użytecznego sprawowania urzędów są potrzebnymi" 28 .

Po drugie, w postanowieniu z 12 listopada 1816 roku odrębnie zaznaczono także - w duchu policystyczno-oświeceniowej wiary w zdolność wpływania na społeczeństwo poprzez właściwie skonstruowane prawo - że władze spodziewają się, iż wykwalifikowany korpus urzędniczy może „wzniecić w Narodzie mocniejsze pobudki do oświecenia i okazać mu rzeczywiste pożytki z nabywanych nauk i z usposobienia" ${ }^{\prime 2}$. W dekrecie wydanym w Księstwie analogiczne oczekiwania nie zostały wyartykułowane.

\section{Podział na klasy. Wykształcenie i praktyka urzędnicza}

O tym, jakim wykształceniem musiał legitymować się kandydat do pracy w służbie państwowej, a także jaka komisja egzaminacyjna będzie właściwa dla badania jego kwalifikacji, decydowała klasa stanowiska urzędniczego („funkcji i urzędu krajowego"), o które się on ubiegał. Posady urzędnicze podzielone zostały na trzy klasy, przy czym w obrębie pierwszej z nich - do której należeli niżsi funkcjonariusze odpowiedzialni za zadania techniczno-porządkowe - wyodrębniono jeszcze dwie grupy stanowisk.

W pierwszej z nich znalazły się urzędy woźnego sądowego, strażnika, dozorcy więzienia, sołtysa, dozorcy robót publicznych, oficjalisty VI i VII rzędu w Korpusie Górniczym oraz akuszera. Ubieganie się o jedną z tych posad warunkowane było przedstawieniem zaświadczenia ukończenia szkoły elementarnej.

Do drugiej grupy zaliczano kancelistów, rysowników, pisarzy i rewizorów niższych komór, podleśniczych, dozorców policyjnych, dozorców konsumpcyjnych, wójtów, chirurgów drugiego rzędu, aptekarzy, konduktorów dróg, mostów, rzek spławnych oraz oficjalistów V rzędu w Korpusie Górniczym. W tym przypadku kandydat zobowiązany był do okazania świadectwa ukończenia szkoły wydziałowej. 
II klasę - urzędników średniego szczebla - tworzyli komisarze (z wyłączeniem komisarzy wojewódzkich i obwodowych należących do III klasy), intendenci policji, skarbu, leśniczy, intendenci więzień publicznych, kasjerzy, kalkulatorzy, kontrolerzy, protokolanci, archiwiści, sekretarze kancelarii i biur, poczmistrze, pisarze i rewizorzy główniejszych komór, geometrzy, „budowniczowie praktyczni", oficjaliści menniczy, oficjaliści Towarzystwa Ogniowego, komornicy, komisarze dróg i spławów, regestratorzy, burmistrzowie, ławnicy oraz "oficjaliści i urzędnicy" IV rzędu w Korpusie Górniczym. W stosunku do tych stanowisk przystąpienie do egzaminu uzależnione było od przedstawienia dowodu ukończenia szkoły wojewódzkiej i zaliczenia egzaminu przed wojewódzką komisją egzaminacyjną. Szczegółowe przepisy w tym zakresie miały zostać wydane przez Komisję Wyznań Religijnych i Oświecenia Publicznego.

Do klasy III grupującej wyższe stanowiska urzędnicze - z wyłączeniem wszakże najwyższych stanowisk, m.in. członków komisji rządowych - należeli „obrońcy sądów wszelkiego stopnia”, prokuratorzy, pisarze sądowi, sędziowie (wymieniano sędziów ziemskich, grodzkich, zjazdowych, apelacyjnych i sędziów Sądu Najwyższego ${ }^{30}$ ), "prezesi”, prezydenci miast, komisarze wojewódzcy i obwodowi, adiunkci, "szefowie w komisjach rządowych", sekretarze generalni i wydziałowi, asesorowie przy "naczelnych władzach”, intendenci, inspektorowie i podinspektorowie dóbr koronnych i narodowych, poborcy i kontrolerzy generalni, członkowie Dyrekcji Dóbr Koronnych i Narodowych, radcowie Izby Obrachunkowej, członkowie Administracji Ogniowej, konsyliarze Rady Lekarskiej, fizycy wojewódzcy i miejscy pierwszego rzędu, chirurdzy obwodowi, urzędnicy II i III rzędu w Korpusie Górniczym. Objęcie jednego z tych urzędów wymagało zaliczenia egzaminu przed Najwyższą Komisją Egzaminacyjną, a podejście do niego uzależnione było z kolei od złożenia zaświadczenia „z ukończonych w swoim przedmiocie nauk w szkole głównej i z odprawionych egzaminów podług przepisów Komisji Oświecenia, tak z nauk we właściwym akademickim wydziale, jako też z praktyki w stosownym do tego wydziału technicznym instytucie" ${ }^{\prime 31}$.

Jak wspominał po latach Fryderyk Skarbek, profesor nauk administracyjnych na Uniwersytecie Warszawskim, uzależnienie uzyskania znaczącej posady $\mathrm{w}$ aparacie administracyjnym od ukończenia studiów spowodowało, iż jego „prelekcje [...] w Uniwersytecie były zawsze licznie uczęszczane nie tylko przez akademików, ale i przez wolnych słuchaczy, i co rok wychodziło z niego po kilkadziesiąt usposobionych uczniów, kandydatów na wyższe urzędy, którzy bądź przy wejściu do służby, bądź przy posuwaniu się w niej, obowiązani byli składać egzaminy, przeto musieli się obznajamiać z naukami administra-

30 Kandydaci na sędziów obieralnych mogli składać egzaminy „w komisjach wojewódzkich przez Delegację od Komisji Najwyższej".

31 „Dziennik Praw Królestwa Polskiego”, t. 2, nr 10, s. 229-232, 239-240. 
cyjnymi, a tym samym czerpać potrzebnych im wiadomości w dziełach odpowiedniej treści"32. Nauczanie akademickie ukierunkowywane zaś było na przygotowanie teoretyczne mimo innych oczekiwań ze strony władz rządowych. Ograniczano się bowiem do wykładów bez zajęć praktycznych, zaś profesorowie - z F. Skarbkiem na czele - skłonni byli raczej do przekazywania wiedzy ogólnoteoretycznej ${ }^{33}$.

Wymóg ukończenia szkoły głównej jako warunku sine qua non przystąpienia do egzaminu przed Najwyższą Komisją również został zaczerpnięty z koncepcji, która ustalona została w Księstwie Warszawskim, ale niewprowadzona tam w życie. Albowiem po powstaniu Szkoły Nauk Administracyjnych w 1811 roku ustalono wprawdzie, iż przystąpienie do egzaminów uzależnione będzie od przedłożenia świadectwa jej ukończenia, jednakże dopiero po upływie sześciu lat od jej otwarcia ${ }^{34}$.

Ustanowienie podziału urzędników na klasy było rozwiązaniem nowym, nieprzewidzianym w treści dekretu z 29 kwietnia 1808 roku. Nie oznacza to jednak, że w Księstwie - bez formalnego wyodrębniania klas - nie grupowano stanowisk urzędniczych. W przeciwieństwie do regulacji zawartych w postanowieniu z 12 listopada 1816 roku był to jednak podział tylko na dwie kategorie, uzależniony wyłącznie od tego, przed którą komisją - departamentową czy Najwyższą - należało zdać egzamin, podczas gdy, jak wiadomo, podział na trzy klasy w Królestwie wynikał z różnych stopni wykształcenia, jakie trzeba było uzyskać. W Księstwie zatem wśród urzędów (określanych jako „niższe”), których obsada wymagała zaliczenia egzaminu przed departamentową komisją, znalazły się stanowiska odpowiadające urzędom należącym do II klasy w Królestwie ${ }^{35}$. Natomiast najwyższe komisje w obu państwach egzaminowały podobny krąg wysokich urzędników (zaliczanych w Królestwie do III klasy) ${ }^{36}$,

32 Pamiętniki Fryderyka hrabiego Skarbka, oprac. P. Mysłakowski, Warszawa 2009, s. 234.

33 W. Sobociński, Wydział Prawa i Administracji Uniwersytetu Królewsko-Warszawskiego (1816-1830), [w:] Studia z dziejów..., s. 77-80, 90.

34 „Dziennik Praw Księstwa Warszawskiego”, t. 3, nr 32, s. 323. Obowiązek przedstawienia świadectwa ukończenia Szkoły Administracyjnej dla urzędników stanowił odpowiednik wcześniej wprowadzonego przepisu z dekretu o ustanowieniu Szkoły Prawa, ustalającego, że „,w dalszym czasie nikt nie może być przyjmowany na urzędy w wydziale sprawiedliwości, kto nie okaże przyzwoitych z tej Szkoły zaświadczeń", ibidem, t. 1, nr 11, s. 297.

35 W dekrecie z 29 kwietnia 1808 r. wymieniano burmistrzów, prezydentów municypalnych, intendentów i komisarzy policji, pisarzy celnych i celników, leśniczych i budowniczych miejskich, zastrzegając przy tym, że jest to jedynie wyliczenie przykładowe, co pozwalało również na poddanie niższych funkcjonariuszy (zaliczonych w Królestwie do I klasy) obowiązkowi egzaminacyjnemu, ibidem, t. 1, nr 4, s. 72 .

36 Według przepisów dekretu z 29 kwietnia 1808 r. egzamin przed Najwyższą Komisją musieli odbyć kandydaci na urząd referendarza, konsyliarza ministerii, sekretarza generalnego w ministerii, prefekta, radcy prefektury, podprefekta, sekretarza generalnego prefektury, intendenta wyższego skarbowego, intendenta policyjnego, komisarza policji (generalnego i departamentowych), prezydenta miasta, nadleśniczego, budowniczego (generalnego i departamentowych), ibidem, s. 73. 
z tym wszakże istotnym zastrzeżeniem, że wśród funkcji i urzędów wymienionych w postanowieniu "o egzaminach" znalazły się także stanowiska w wymiarze sprawiedliwości oraz szerszy krąg urzędów administracji specjalnej.

Żaden z urzędników nie musiał natomiast legitymować się wykształceniem prawniczym. Obowiązek uzyskania stopnia magistra prawa spoczywał tylko na osobach ubiegających się o urząd obrońcy sądowego przy sądzie I instancji, zaś przy wyższych sądach wymagany był nawet doktorat ${ }^{37}$. Podobnie, „usposobieni w naukach lekarskich" na chirurgów (miejskich, powiatowych i obwodowych) zobowiązani zostali do przedstawienia dyplomu magistra medycyny i chirurgii lub przynajmniej chirurgii, zaś na fizyków (wojewódzkich i miasta Warszawy) - dyplomu doktora w analogicznych dziedzinach ${ }^{38}$.

Odnośnie do honorowania wykształcenia uzyskanego poza rodzimym systemem oświatowym w postanowieniu z 12 listopada 1816 roku zastrzegano przede wszystkim, że „edukacja za granicą lub prywatna" nie jest wystarczająca do ubiegania się o posadę i wymaga zaliczenia "egzaminu publicznego w krajowych szkołach, stosownie do funkcji lub urzędów pierwszej lub drugiej klasy", oraz przedstawienia właściwej komisji odpowiedniego zaświadczenia $^{39}$. Ponadto ustalono, że "ci, którzy nauki odbyli w szkołach lub akademiach zagranicznych bez otrzymania oznaczonego we właściwym wydziale swoich nauk stopnia, winni w szkole głównej krajowej albo w szkole specjalnej akademickiej złożyć przepisane egzaminy lub uzyskać stosowne zaświadczenia"40. Wymagane było zatem przynajmniej potwierdzenie jakości zdobytego wykształcenia przez krajową szkołę, która jednak mogła zażądać uprzedniego zaliczenia wybranych przez siebie egzaminów. Takich utrudnień nie zdecydowano się jednak czynić „cudzoziemcom biegłym w naukach górniczych, w naukach komunikacji i lądowej i wodnej oraz w nauce leśnictwa", którym zagwarantowano, iż „przeniósłszy się do Królestwa Polskiego będą mogli bez egzaminu w takim stopniu obejmować stosowne do ich nauk funkcje i urzędy, w jakim stopniu funkcje i urzędy w swoim kraju już sprawowali"41.

Oprócz wykształcenia każdy z kandydatów na urząd (dowolnej klasy) musiał także rekomendować się doświadczeniem w postaci „dwuletniej ciągłej

37 Wysokie wymagania stawiane osobom ubiegającym się o zatrudnienie $\mathrm{w}$ wymiarze sprawiedliwości i służbie zdrowia charakteryzowały również stosunki w Księstwie Warszawskim po utworzeniu Szkoły Prawa oraz Wydziału Lekarskiego w Ministerstwie Spraw Wewnętrznych, zob. A. Winiarz, Organizacja..., s. 451-452.

38 Na podstawie postanowienia namiestnika z 21 czerwca 1817 r. ustalono, że świadectwa kwalifikacyjne dla lekarzy wydawane będą po przeprowadzeniu egzaminów praktycznych, organizowanych na Wydziale Lekarskim Królewskiego Uniwersytetu Warszawskiego. Wyniki przesyłane były do oceny dla Rady Ogólnej Lekarskiej, która również przeprowadzała egzamin teoretyczny, zob. ibidem, s. 455.

39 „Dziennik Praw Królestwa Polskiego”, t. 2, nr 10, s. 236.

40 Ibidem, s. 240.

41 Ibidem, s. 242. 
praktyki jako aplikant przy stosownych publicznych funkcjach lub urzędach", z których musiał przedstawić stosowne zaświadczenie. Dodawano przy tym, że „przerwy w czasie aplikacji praktycznej z jakiejkolwiek przyczyny zachodzące nie mogą być rachowane w ciąg dwuletniej aplikacji; owszem o tyleż czas praktycznego usposobienia przedłużać będą"42.

Nieco inaczej i mniej precyzyjnie wymogi wykształcenia i doświadczenia w służbie publicznej zostały określone w dekrecie z 29 kwietnia 1808 roku. Ustalono w nim bowiem, że obok złożenia metryki chrztu i zaświadczenia o nienagannej postawie moralnej kandydat stawający przed departamentową komisją egzaminacyjną był zobowiązany przedstawić dokument stwierdzający odbyte nauki oraz opinię o dotychczasowej pracy w urzędzie ${ }^{43}$.

\section{Procedura egzaminacyjna}

Ukończenie właściwej szkoły i odbycie praktyki nie było wystarczające dla przyjęcia do służby. „Każdy [bowiem] starający się o funkcję lub urząd publiczny” był zobowiązany "wprzód swoje usposobienie przez egzamin wykazać w komisjach egzaminacyjnych"44. Wyjątkowo tylko kandydaci ubiegający się o stanowisko w klasie I należące do pierwszej grupy składali egzamin przed deputacją wyłonioną $\mathrm{z}$ komisji ${ }^{45}$. W Królestwie przejęto zatem rozwiązanie zastosowane $\mathrm{w}$ Księstwie (obowiązujące $\mathrm{w}$ pełni od 1 września $1810 \mathrm{roku}^{46}$ ). Postanowienie z 12 listopada 1816 roku przewidywało powołanie komisji wojewódzkich, właściwych do przeprowadzania egzaminów dla kandydatów na urzędy II klasy i Najwyższej Komisji Egzaminacyjnej sprawdzającej wiedzę urzędników aspirujących do objęcia posad zaliczanych do III klasy ${ }^{47}$.

42 Ibidem, s. 236-237.

43 „Dziennik Praw Księstwa Warszawskiego", t. 1, nr 4, s. 73. Dekretem z 1 sierpnia 1810 r. wprowadzono też furtkę dla tych, którzy swoją edukację zakończyli przed 1807 r., rezygnując z domagania się od nich świadectw ukończenia nauk, zob. M. Krzymkowski, op. cit., s. 42.

44

45

46 wiązywać dopiero od 1 września 1809 r., zaś od 1 września 1810 r. obligatoryjne stawały się egzaminy przed Najwyższą Komisją Egzaminacyjną - „Dziennik Praw Księstwa Warszawskiego”, t. 1, nr 4, s. 71, 74. Opóźnienie, uzasadnione zapewne koniecznością przygotowania stosownych rozwiązań instytucjonalnych, nie oznaczało bynajmniej, że rząd Księstwa rezygnował z jakiejkolwiek oceny kwalifikacji osób ubiegających się o urzędy. W tym celu ustanowiono uproszczoną metodę badania kwalifikacji kandydatów, obowiązującą już od dnia ogłoszenia dekretu z 29 kwietnia 1808 r. Polegała ona na przyznaniu „pierwszeństwa tym, którzy przez odbycie poprzedniczych egzaminów udowodnią wyjaśnione wyobrażenia o stosownych do urzędu obowiązkach oraz należytą praktyczną wprawę", ibidem, s. 70-71.

47

„Dziennik Praw Królestwa Polskiego”, t. 2, nr 10, s. 226

Ibidem, s. 245.

„Dziennik Praw Królestwa Polskiego”, t. 2, nr 10, s. 232. 
Komisje egzaminacyjne miały zostać ustanowione po jednej w każdym województwie, analogicznie jak w Księstwie, w którym komisje powoływano w departamentach. Przewidziano, że będą one miały charakter kolegiów urzędniczych. Komisja egzaminacyjna miała bowiem funkcjonować pod prezydencją głównego urzędnika administracji lokalnej - prezesa komisji wojewódzkiej, tak jak wcześniej obradowała pod przewodnictwem prefekta ${ }^{48}$. W jej skład wchodzili ponado komisarze wojewódzcy, zastępując wyższych urzędników departamentowych z czasów Księstwa (radców prefektury, intendenta skarbowego i policyjnego, nadleśniczego oraz budowniczego departamentowego). W Królestwie dodatkowo jednak do komisji dokooptowano także rektora szkoły wojewódzkiej oraz „dwóch doświadczonych lub na urzędzie będących znawców rzeczy przybranych przez prezesa podług potrzeby", czyli specjalistów w danej dziedzinie, wybieranych stosownie do działu administracji, w którym miał być zatrudniony kandydat - odpowiednio: budownictwa, komunikacji lądowej i wodnej, górnictwa, służby zdrowia, leśnictwa oraz sądownictwa. Rozszerzenie członków komisji egzaminacyjnych o wyspecjalizowany czynnik ekspercki stanowiło niewątpliwie ułatwienie dla prawidłowej merytorycznej oceny kandydatów nie tylko pod kątem ich kwalifikacji ogólnych, ale i specjalizacji branżowej właściwej dla działu administracji, do którego aplikował ubiegający się o urząd. Do prawomocności orzeczeń komisji niezbędny był komplet składający się z minimum 5 członków, w tym obligatoryjnie jeden „znawca" 49 .

Początkowo egzaminy rekrutujące urzędników do administracji górniczej organizowane były wyłącznie przez Komisję Egzaminacyjną Województwa Krakowskiego wobec faktu, że siedzibą Dyrekcji Górniczej były Kielce. Urzędy zarządu leśnego obsadzane były z kolei na podstawie decyzji wydawanych przez komisję województwa mazowieckiego. W późniejszym okresie upoważnienie do przeprowadzania tychże egzaminów uzyskały jednak i pozostałe wojewódzkie komisje egzaminacyjne ${ }^{50}$.

Przy Radzie Stanu ustanowiona została Najwyższa Komisja Egzaminacyjna, stanowiąca również kontynuację swej imienniczki z poprzedniego okresu. Skład osobowy Najwyższej Komisji ustalany był na podobnych za-

48 Kwestia obejmowania przewodnictwa w wojewódzkiej komisji egzaminacyjnej z urzędu przez prezesa komisji wojewódzkiej budziła jednak kontrowersje, skoro Najwyższa Komisja Egzaminacyjna przychyliła się do wniosku Komisji Rządowej Sprawiedliwości, aby wnioskować o zmianę postanowienia z 12 listopada $1816 \mathrm{r}$. w tym względzie. Zaproponowano, aby przewodniczący wojewódzkiej komisji egzaminacyjnej wybierany był przez namiestnika z grona kandydatów przedstawionych przez Najwyższą Komisję Egzaminacyjną, „niewyłączając jednak prezesa komisji wojewódzkiej", AGAD, I RS KP, sygn. 67, k. 20.

49 „Dziennik Praw Królestwa Polskiego", t. 2, nr 10, s. 226-228; por. „Dziennik Praw Księstwa Warszawskiego", t. 1, nr 4, s. 74 .

50 A. Winiarz, Organizacja..., s. 455. 
sadach jak w przypadku komisji wojewódzkiej. Wchodzili bowiem do niej najwyżsi urzędnicy szczebla centralnego - minister wyznań religijnych i oświecenia publicznego jako prezydujący, minister właściwy resortowo dla posady, o którą ubiegał się kandydat, prezes Izby Obrachunkowej, po jednym radcy stanu z każdej z komisji rządowych, dwóch referendarzy, „dwóch członków Akademii stosownie do przedmiotu egzaminu" (przedstawiciel Wydziału Prawa i Administracji oraz Wydziału Lekarskiego ${ }^{51}$ ) oraz "dwóch przez prezesa wezwanych znakomitych urzędem lub doświadczeniem znawców", reprezentujących - podobnie jak w przypadku wojewódzkich komisji - branże budownictwa, komunikacji lądowej i wodnej (w obu przypadkach reprezentowanych przez "dwóch przybranych w tej sztuce biegłych urzędników Komisji Rządowej Spraw Wewnętrznych"), górnictwa (dwóch członków Wydziału Górniczego KRSW i dwóch biegłych z Dyrekcji Górniczej), służby zdrowia (dwóch członków Rady Lekarskiej), leśnictwa („dwóch biegłych w leśnictwie”), a także sądownictwa (dwóch sędziów Sądów Najwyższego i apelacyjnego) ${ }^{52}$. Skład Najwyższej Komisji Egzaminacyjnej był szerszy i częściowo ustalony na innych zasadach aniżeli w Księstwie ${ }^{53}$, ale w obu przypadkach komisje tworzono z grona centralnych urzędników najwyższych szczebli.

Komisja miała orzekać w kompletach siedmioosobowych, w tym dwóch "znawców" ${ }^{\prime 54}$. Do ich fachowej opinii prawodawca przykładał zresztą szczególne znaczenie, o czym świadczy rozwiązanie, w myśl którego, w przypadku gdyby ocena komisji była odmienna aniżeli opinia znawców, a ich głosy znalazłyby się w mniejszości, wówczas żądano, aby „rozpis z protokołem na żądanie któregokolwiek członka komisji egzaminacyjnej” był „przesłany do Najwyższej Komisji Egzaminacyjnej pod ostateczne rozstrzygnięcie" 55 .

Najwyższa Komisja Egzaminacyjna sprawowała zarazem nadzór nad wojewódzkimi komisjami, będąc odpowiedzialną za „pilnowanie porządku przepisanego w komisjach egzaminacyjnych wojewódzkich, prostowanie ich uchybień, odbieranie od nich, po każdym odbytym egzaminie, wyciągów protokołu

51 Ibidem, s. 453.

52 „Dziennik Praw Królestwa Polskiego”, t. 2, nr 10, s. 232-233.

53 Przewodniczącym Najwyższej Komisji Egzaminacyjnej w Księstwie nie był prezes Izby Edukacyjnej (występujący w charakterze najwyższego urzędnika działu edukacji nominalnie tylko zależnego od ministra spraw wewnętrznych), a prezes Rady Stanu. W jej skład wchodzili zaś wszyscy ministrowie oraz po jednym referendarzu i konsyliarzu ministerii „od każdego z ministrów”, a „w potrzebie” także naczelny nadleśniczy i generalny budowniczy - „Dziennik Praw Księstwa Warszawskiego", t. 1, nr 4, s. 75.

54 „Dziennik Praw Królestwa Polskiego”, t. 2, nr 10, s. 234. Kwestia tak szerokiego kompletu była problematyczna. W rezultacie Najwyższa Komisja Egzaminacyjna zwróciła się do namiestnika z wnioskiem, „aby dla pewniejszego zebrania się kompletu komplet w Komisji Najwyższej Egzaminacyjnej składał się z 5 osób [...] Często bowiem w czasie posiedzeń oznaczonych zaświadczała brak kompletu i takowe przymuszoną była odraczać", AGAD, I RS KP, sygn. 67, k. 21. 
tegoż egzaminu oraz stanowienie w przypadkach zaszłych rozpisów"56. Czyniła to na podstawie dokumentów, do których przesyłania były zobowiązane komisje wojewódzkie: corocznego ogólnego raportu ze swych czynności oraz przesyłanej po każdym odbytym egzaminie listy egzaminowanych kandydatów „z wymienieniem ich klasy, przedmiotu odbytego egzaminu i stopnia zdolności" ${ }^{57}$.

Z kolei kontrolę nad Najwyższą Komisją Egzaminacyjną sprawowała Rada Stanu. Również kluczowe znaczenie dla tej oceny mogły mieć coroczne raporty, które Komisja była zobowiązana jej składać „z uwag i spostrzeżeń, jakie przy roztrząsaniu przesłanych protokołów uczyni” i „swojego rozstrzygnięcia rozpisów”. Raport miał zawierać sprawozdanie „z aktualnego stanu czynności i postępowania Komisji Egzaminacyjnej” oraz przedstawione „środki do ich udoskonalenia" ${ }^{\prime 58}$. Natomiast postanowienie z 12 listopada 1816 roku nie wspominało o obowiązku przesyłania Radzie Stanu list egzaminowanych kandydatów.

Aby przeciwdziałać nepotyzmowi, ustanowiono - dość ograniczoną, jak się wydaje - zasadę, że egzaminatorzy, tak w wojewódzkich, jak i w Najwyższej Komisji, nie mogli być krewnymi pierwszego lub drugiego stopnia w stosunku do kandydata ${ }^{59}$.

Wprawdzie w postanowieniu „o egzaminach” wiele kwestii zostało już uregulowanych w większym lub mniejszym stopniu szczegółowości (czym akt ten wyraźnie odróżniał się od znacznie mniej rozbudowanego dekretu z 29 kwietnia 1808 roku), zarazem jednak w treści tego aktu prawnego wyraźnie upoważniono Najwyższą Komisję do wydawania wykonawczych przepisów konkretyzujących tryb funkcjonowania systemu egzaminacyjnego ${ }^{60}$. Dawało to asumpt do wprowadzenia w nim odrębności zależnie od działu administracji. Przede wszystkim Najwyższa Komisja przygotowała kompleksowe zmiany w zakresie ustalenia trybu egzaminacyjnego względem kandydatów do pracy $\mathrm{w}$ resorcie sprawiedliwości. W niektórych punktach wymagały one nowelizacji postanowienia z 12 listopada 1816 roku i dlatego musiały zostać zaakceptowane przez namiestnika w formie postanowienia zmieniającego. Ustalona została szczegółowa lista wszystkich stanowisk w resorcie sprawiedliwości z przyporządkowaniem ich do właściwych klas. Najniżsi oficjaliści sądowi zostali wyłączeni spod obowiązku zaliczenia egzaminów zwyczajnych, a „uznanie ich zdatności” uzależniono od decyzji „prezydującego we właściwym sądzie”. Rozszerzony został też skład zarówno wojewódzkich,

\footnotetext{
56 Ibidem, s. 234.

57 Ibidem, s. 253.

58 Ibidem, s. 234-235.

59 Ibidem, s. 251-252.

60 Ibidem, s. 251.
} 
jak i Najwyższej Komisji Egzaminacyjnej ${ }^{61}$. Podobne szczegółowe zasady ustalone zostały również w służbie zdrowia ${ }^{62}$.

Przystąpienie do egzaminu uzależnione było od przedstawienia kompletu zaświadczeń, na które składały się: dokument potwierdzający „usamowolnienie lub zezwolenie rodziców lub opiekunów", „świadectwo ze szkół”63, „świadectwo miejscowej policji ze swego pobytu”, „świadectwo z odbytej praktyki aplikanta", życiorys („,opis biegu swojego życia"), a ponadto względem kandydata ubiegającego się o posadę należącą do II bądź III klasy "wyciągi robione z dzieł przez siebie po skończonej edukacji czytanych i dokładne wyłożenie ich treści", zaś względem osoby przystępującej do egzaminu przed Najwyższą Komisją Egzaminacyjną, czyli ubiegającego się o urząd III klasy, dodatkowo także zaświadczenia o zaliczeniu egzaminu przed wojewódzką komisją egzaminacyjną oraz odbyciu praktyk "przy jakim do swych nauk stosownym urzędzie” bądź że "stosowny urząd przynajmniej przez rok jeden sprawował”, wraz z załączonym od zwierzchniej władzy zaświadczeniem o „swym w obowiązkach pilnym i moralnym sprawowaniu"64. Postanowienie to powtarzało treść dekretu z 29 kwietnia 1808 roku zarówno w zakresie obowiązku uprzedniego zaliczenia egzaminu przed komisją egzaminacyjną niższego szczebla (w tym przypadku departamentową), jak i co najmniej rocznej praktyki urzędniczej odbytej po tymże egzaminie ${ }^{65}$.

Egzaminy w wojewódzkich komisjach egzaminacyjnych miały odbywać się dwa razy w roku (w styczniu i w sierpniu). Wymagano, by były one protokołowane. Niedopuszczenie do egzaminu przez komisję powinno zostać przez nią uzasadnione. Egzamin składać się miał zarówno z części teoretycznej, jak i praktycznej („robót, pism, rachunków, planów itp.”), a sesja egzaminacyjna miała trwać łącznie przynajmniej trzy godziny. Wystawione przez komisję świadectwo z egzaminu miało zawierać, oprócz klasy urzędu i przedmiotów egzaminacyjnych, ocenę „zdolności” egzaminowanego „do sprawowania funkcji i urzędów” z wyszczególnieniem "stopnia okazanej zdolności w ustnych odpowiedziach i praktycznych wywodach", „w czym kandydat celuje i jakie umie języki". Komisja podejmowała decyzje większością głosów ${ }^{66}$. W przypadku, gdy odmówiono kandydatowi przyznania „,́́wiadectwa zdatności”, komisja zobowiązana była "wymienić tego powody i wskazać mu razem środki do dalszego w czym należy usposobienia".

61 AGAD, I RS KP, sygn. 67, k. 19-22.

62 A. Winiarz, Organizacja..., s. 455.

63 W przypadku egzaminu na urzędy III klasy, czyli odbywanego przed Najwyższą Komisją, zaświadczenie miało przedstawiać dodatkowo wyniki zaliczonych egzaminów w szkole głównej.

64 „Dziennik Praw Księstwa Warszawskiego", t. 1, nr 4, s. 73.

65 „Dziennik Praw Królestwa Polskiego”, t. 2, nr 10, s. 243.

66 W przypadku różnicy zdań zarządzano głosowanie „przez kreskowanie”, a „zdanie mniejszość głosów za sobą mające równie w protokole zapisane będzie". 
Model egzaminu przed Najwyższą Komisją w znacznym stopniu odzwierciedlał zasady egzaminowania przed komisjami wojewódzkimi. Zgłoszenie się kandydata do „najwyższego egzaminu” wymagało z kolei (oprócz sprawdzenia, czy załączył on komplet dokumentów) uprzedniego wyznaczenia „czasu i przedmiotu, z którego ma wypracować na piśmie raporty, referaty, zdania, uwagi lub rozprawy albo inne stosowne dzieła praktyczne". Analogicznie jak przed wojewódzką komisją przynajmniej trzygodzinny egzamin składał się z części teoretycznej i praktycznej. Jakkolwiek postanowienie z 12 listopada 1816 roku w tej kwestii nie stawiało żadnych warunków formalnych, część teoretyczna miała charakter ustny i koncentrowała się na sprawdzeniu wiedzy specjalistycznej ${ }^{67}$. Natomiast ocena wykonanej przez kandydata („pod bezpośrednim nadzorem egzaminatora”68) pracy praktycznej - odmiennie niż w przypadku egzaminu przed komisją wojewódzką zapewne z uwagi na większy stopień skomplikowania powierzonych zadań poprzedzona jednak musiała być indywidualnym wstępnym sprawdzeniem dokonanym przez wydelegowanego członka Najwyższej Komisji Egzaminacyjnej. Po złożeniu jego opinii i po rozstrzygnięciu przez Najwyższą Komisję, „czyli pisma przez podającego się wygotowane były"69, przewodniczący Komisji przekazywał „egzaminu dzieło” do referatu jednego z jej członków. Obowiązkiem zaś referenta było „rozważyć najgruntowniej powierzone mu pisma, dostrzeżone uchybienia wyszczególnić, swoje zdanie umieścić i rzecz przedstawić Komisji”. Dopiero na tej podstawie Komisja, „uznawszy egzaminowanego zdolność", wydawała mu stosowne zaświadczenie i nakazywała wpisać go na „listę usposobionych". W przypadku zaś, gdy podjęła decyzję o tym, iż „zaświadczenie zdolności nie może być wydane”, była zobowiązana do wskazania egzaminowanemu, „w czym jeszcze mu się usposobić trzeba" ${ }^{\prime 70}$.

W postanowieniu „o egzaminach" - odmiennie niż w Księstwie Warszawskim, w którym stosownie do treści dekretu z 29 kwietnia 1808 roku „sposób odbywania egzaminów" miał być określony przez Najwyższą Komisję Egzaminacyjną ${ }^{71}$ - ustalono przedmioty egzaminu kwalifikacyjnego. Mogły to być następujące dziedziny:

A Winiarz, Organizacja..., s. 454.

Ibidem, s. 454.

Wydaje się, że szczególnie względem egzaminu przeprowadzanego przed Najwyższą Komisją mogła znaleźć zastosowanie sankcja „utraty prawa do urzędów”, w przypadku "gdyby się okazało, iż kandydat w egzaminie praktycznym pisma nie sam, ale za pomocą cudzą wypracowane w komisji złożył", jakkolwiek przepis ten formalnie mógł znaleźć zastosowanie także przy egzaminie organizowanym przez wojewódzką komisję.

„Dziennik Praw Królestwa Polskiego”, t. 2, nr 10, s. 247.

„Dziennik Praw Księstwa Warszawskiego”, t. 1, nr 4, s. 72. 
1) znajomość obowiązującego prawa, na które - według wyliczenia przeprowadzonego w postanowieniu z 12 listopada 1816 roku - składały się następujące (traktowane jako odrębne) przedmioty: a) Ustawa Konstytucyjna Królestwa, b) „prawa i dekrety Księstwa Warszawskiego”, c) „postanowienia rządu Królestwa" oraz inne obowiązujące przepisy z zakresu d) „prawa publicznego, cywilnego i kryminalnego” oraz e) „postępowania sądowego";

2) bliżej niesprecyzowana wiedza ogólnoadministracyjna, kryjąca się pod sformułowaniem f) „krajowa administracja i policja”;

3) wiedza fachowa obejmująca: g) „statystykę”, h) „naukę skarbową”, i) „krajowy systemat podatkowania i manipulacji skarbowej”, j) „naukę rachunkowości”, k) „urządzenie poczty”, 1) „nauki lekarskie”, m) „technologię”, n) „budownictwo”, o) „naukę leśniczą”, p) „naukę komunikacji lądowej i wodnej” oraz r) „nauki górnicze, kopalń, hutnictwa i fabryk"72.

Kandydat mógł poddać się egzaminowi zarówno z jednego, jak i z kilku przedmiotów, przy czym w tym drugim przypadku mógł być egzaminowany jedynie z każdej dziedziny z osobna. Przedmioty egzaminu dzieliły się „ze względu na różne gatunki służby i urzędów publicznych". W postanowieniu „o egzaminach” nie ustalono jednak ściśle, z jakiej konkretnie materii kandydat na dany urząd będzie egzaminowany, ograniczając się jedynie do ogólnej konstatacji, iż będą to przedmioty, „których znajomość jest potrzebna dla sprawowania funkcji i urzędów, do jakich się podający ubiega". Szczególnie nie jest jasne, czy w każdym przypadku i w jednakowym zakresie wymagano znajomości pewnych przynajmniej elementów wiedzy prawniczej bądź ogólnoadministracyjnej jako wiadomości, których przydatność była przynajmniej do pewnego stopnia uniwersalna. Ponadto warto zwrócić uwagę, że twórcy systemu egzaminowania zakładali, iż zakres przedmiotowy egzaminu przed Najwyższą Komisją Egzaminacyjną powinien być ustalany przy uwzględnieniu „wyciągów z dzieł po skończonej edukacji czytanych” przez kandydata ${ }^{73}$.

Niedookreśloność wymagań egzaminacyjnych budziła kontrowersje, które próbowała wyjaśnić Najwyższa Komisja Egzaminacyjna. W wydanych przez nią przepisach wykonawczych dla wojewódzkich komisji ustalono m.in., że na posady administracyjno-sądowe niepotrzebne jest zdawanie egzaminu z prawa. „Dostateczną dla nich będzie wiadomością materia tyczyć się mająca właściwych czynności i obowiązków tudzież poprzednia aplikacja art. 19 postanowienia o egzaminach zastrzeżona". Prawdopodobnie również w innych dziedzinach administracji dokonano podobnego rozróżnienia, koncentrując się zwłaszcza na wyodrębnieniu „posad wymagających wiadomości [z] teo- 
rii i praktyki prawa” od "posad wcale tego niepotrzebujących"74. W nawiązaniu do tych wytycznych Komisja Rządowa Sprawiedliwości zwróciła się z wnioskiem względem właściwych jej resortowo stanowisk, aby tylko urzędy i funkcje sądowe, które proponowała zaliczyć do II klasy podlegały obowiązkowi egzaminu z "nauk teoretycznych i praktycznych", podczas gdy wymienione w piśmie stanowiska niższych funkcjonariuszy administracji sądowej jako należące do I klasy zwolnione były ze sprawdzania wiedzy teoretycznej. Dezyderat został zaakceptowany przez Najwyższą Komisję, która ustaliła, „by oficjaliści sądowi do klasy I policzeni nie należeli do egzaminów zwyczajnych, lecz tylko uznanie ich zdolności od prezydujących w właściwych sądach zależało"75. Najwyższa Komisja zwróciła się nawet do namiestnika z wnioskiem, aby „oficjaliści sądowi teraz w I klasie proponowani wyłączeni byli od art. 1 postanowienia z 12 listopada 1815 (sic!) przepisującego wyraźnie, iż każdy starający się o funkcję albo urząd ma wprzód swoje usposobienie przez egzamin okazać w komisji egzaminacyjnej, i żeby w te miejsce uznaniu ich zdolności od prezydujących we właściwych sądach zależało, wyłączając jednak komorników, którzy obowiązani będą składać egzamin z postępowania sądowego"76.

W przypadku negatywnego wyniku egzaminu na urząd należący do wyższej klasy, kandydat mógł przystąpić jedynie do egzaminu na urząd niższej klasy. Natomiast do egzaminu przed Najwyższą Komisją Egzaminacyjną można było przystępować dwukrotnie ${ }^{77}$. Przy tym każdy egzamin „złożony bez otrzymania chlubnego zaświadczenia" nie mógł być powtórzony wcześniej aniżeli przed upływem roku ${ }^{78}$.

Porównując sytuację w Księstwie Warszawskim należy w pierwszej kolejności zauważyć, że w dekrecie z 29 kwietnia 1808 roku nie został ustalony sposób egzaminowania. Zadanie to powierzone zostało samej Najwyższej Komisji Egzaminacyjnej na podstawie projektu sporządzonego przez K. Woydę. Jako że przedstawiony przez niego projekt wzbudził kontrowersje, Najwyższa Komisja ostatecznie przyjęła jego dość gruntownie zmodyfikowaną wersję,

74 AGAD, I RS KP, sygn. 67, k. 19. Informacja o wydaniu tych przepisów pochodzi z pisma Komisji Rządowej Sprawiedliwości. Znajduje się tam też wzmianka, że Najwyższa Komisja ustaliła szczegółowy tryb egzaminowania nie tylko dla komisji wojewódzkich, ale odrębnie również dla siebie, ibidem, k. 20; zob. też: Obraz Królestwa Polskiego w okresie konstytucyjnym, t. 1: Raporty Rady Stanu Królestwa Polskiego z działalności rządu w latach 1816-1828, oprac. J. Leskiewiczowa, F. Ramotowska, Warszawa 1984, s. 44 (przypis 61).

AGAD, I RS KP, sygn. 67, k. 19-20.

76 Ibidem, k. 23.

77 Według reguł dekretu z 29 kwietnia 1808 r. niezależnie od komisji (Najwyższej bądź departamentowej) dopuszczalne były trzy podejścia do egzaminu, „Dziennik Praw Księstwa Warszawskiego”, t. 1 , nr 4 , s. 73 .

78 „Dziennik Praw Królestwa Polskiego”, t. 2, nr 10, s. 244. 
przygotowaną przez S. Staszica ${ }^{79}$. Według ustalonych w ten sposób zasad egzamin w Księstwie - tak jak w Królestwie - składał się z części pisemnej i ustnej. Wymagano kwalifikacji i wiedzy ogólnej oraz wiadomości specjalnych - z zakresu tego działu administracji, do którego aplikował kandydat, nie ustalając jednak szczegółowo jej zakresu. Za to nakazywano zwrócić uwagę „na rozsądek kandydata, na jego przytomność umysłu, pojętność, na wyobrażenia jasne, sposób tłumaczenia się dokładny; w pismach na charakter piśmienny, na ortografię, na stylu łatwość, niezawisłość, na posiadanie rodowitego języka" 80 . Ponadto dobrze widziana była znajomość języków obcych, zwłaszcza francuskiego i niemieckiego ${ }^{81}$.

Wymagania względem kandydata „podającego się za usposobionego do Najwyższej Komisji Egzaminacyjnej", czyli poddającego się egzaminowi, który otwierał drzwi do piastowania urzędów najwyższej III klasy, zostały skumulowane. Ubiegający się o posadę zobowiązany został do okazania zaświadczenia nie tylko co do tego, że ukończył on szkołę główną, ale również iż uprzednio zaliczył egzamin przed wojewódzką komisją egzaminacyjną (a zatem ukończył też szkołę wojewódzką i odbył dwuletnią nieprzerwaną praktykę urzędniczą), oraz dodatkowo, że „był praktykantem przy jakim do swych nauk stosownym urzędzie albo stosowny urząd przynajmniej przez rok jeden sprawował" już po egzaminie przed wojewódzką komisją. Ponadto kandydat nie mógł przystępować do egzaminu w Najwyższej Komisji wcześniej aniżeli po dwóch latach „odbytego urzędowania” po zaliczeniu egzaminu w komisji wojewódzkiej ${ }^{82}$.

W świetle pamiętnika F. Skarbka, członka Najwyższej Komisji Egzaminacyjnej i profesora nauk administracyjnych w Uniwersytecie Warszawskim, Komisja pod przewodnictwem S. Staszica egzaminowała kandydatów w sposób bardzo liberalny. „Zadanie to nie było łatwym - pisał F. Skarbek - gdyż wypadało egzaminować wszystkich urzędników administracyjnych pod względem usposobienia ich naukowego, a że po większej części starsi ciż urzędnicy prawie żadnego takiego usposobienia nie mieli, zachodziła przeto potrzeba nader względnego ich badania i niewymagania od nich wiadomości, jakie się tylko w młodym wieku z łatwością wymagają"83. Takie postępowanie Komisji

79 Protokoły..., s. 318. Jak ustalił A. Winiarz, na pierwszym posiedzeniu Najwyższej Komisji Egzaminacyjnej 20 czerwca 1808 r. obradowano nad przedstawionym przez K. Woydę projektem organizacji egzaminów. Po burzliwej dyskusji zwrócono się do S. Staszica o przygotowanie zmodyfikowanej wersji projektu, co nastąpiło 5 września.

80 Cyt. za: A. Winiarz, Organizacja..., s. 449.

81 Ibidem, s. 449. Na temat przebiegu niektórych egzaminów i zakresu wymaganej wiedzy zob. ibidem, s. 457; M. Krzymkowski, op. cit., s. 43-44.

82 „Dziennik Praw Królestwa Polskiego", t. 2, nr 10, s. 250.

83 Pamiętniki..., s. 234. 
było więc efektem słabego przygotowania teoretycznego kandydatów. Komisja nie chciała pozbawiać szans na zdanie egzaminu osób doświadczonych już w służbie tylko z tego względu, że ewidentnie nie byli oni wystarczająco wyedukowani. Był to więc klasyczny symptom stadium przejściowego, w którym państwo dopiero wdrażało nowy system pełnego uzawodowienia korpusu urzędniczego.

Zaliczenie egzaminu skutkowało otrzymaniem przez kandydata stosownego zaświadczenia i wpisem na "listę usposobionych kandydatów". Lista ta miała być podana do publicznej wiadomości i przesyłana do wszystkich komisji rządowych oraz rad wojewódzkich, czyli kolegiów odpowiedzialnych za wszczynanie procedur nominacyjnych na urzędy poprzez przedstawianie kandydatów. Skreślony z listy mógł być tylko ten "oficjalista lub urzędnik", który "utracił swoje miejsce za urzędowym wyrokiem”" 84 . W postanowieniu z 12 listopada 1816 roku zastrzegano przy tym solennie, że „żadna władza krajowa nie ma ani przedstawiać ani mianować na urzędy lub funkcje osób nieegzaminowanych podług powyższych przepisów i zaświadczenia zdolności niemających". Od tej zasady czyniono jednak istotny w kontekście stosunkowo krótkiej egzystencji konstytucyjnego Królestwa Polskiego wyłom, formalnie jednak tylko o przejściowym charakterze. Wszyscy bowiem „oficjaliści i urzędnicy, którzy do dnia publikacji tego postanowienia" byli już zatrudnieni „w służbie publicznej” zostali zwolnieni z obowiązku zaliczenia egzaminów "do posiadania funkcji lub urzędów w klasie, w której już się znajdują" ${ }^{85}$. Było to szczególnie ważne, jeżeli się weźmie pod uwagę, iż wejście w życie postanowienia "o egzaminach" nastąpiło bezpośrednio po dokonanych już nominacjach na urzędy. Wprawdzie szereg stanowisk urzędniczych stanowiło kontynuację zbliżonych lub całkiem tożsamych posad z czasów Księstwa, a znaczna liczba dawnych urzędników dalej piastowała swoje funkcje w administracji nowego państwa ${ }^{86}$, ale i tak w fazie organizacyjnej Królestwa doszło do stosunkowo szerokiej wymiany $\mathrm{kadr}^{87}$. Z tego powodu w latach 1813-1815 odnotowano zjawisko masowego ubiegania się młodzieży szkolnej o zatrudnienie $\mathrm{w}$ administracji, które wywołało nawet reakcję ze strony ówczesnego Wydziału Oświecenia Publicznego. Zwrócił się on bowiem o wydanie przez Rząd Tymczasowy zakazu przyjmowania do urzędów bez ukończenia właściwej szkoły ${ }^{88}$.

84 mógł on wówczas podchodzić również do egzaminu przed Najwyższą Komisją.

85

86 A. Winiarz, Organizacja..., s. 453.

87 Sz. Askenazy, Wstęp, w: J. Bojasiński, Rządy Tymczasowe w Królestwie Polskim, maj-grudzień 1815, Warszawa 1902, s. XIV.

88 A. Winiarz, Organizacja..., s 452-453. 
Zwolnienie z procedury rekrutacyjnej ustalonej postanowieniem z 12 listopada 1816 roku nie było jednak pełne, gdyż ewentualny awans na wyższy urząd miał wiązać się już z obowiązkiem zaliczenia egzaminu właściwego dla danej klasy ${ }^{89}$.

Pewne trudności, przynajmniej na początkowym etapie, mógł sprawić wymóg wykształcenia. Wprawdzie dyplomy ukończenia szkół w Księstwie Warszawskim były honorowane, ale część z nich w okresie organizacyjnym Królestwa Polskiego 1813-1816 zaprzestała działalności, co spowodowało, że na absolwentów, którzy osiągnęli odpowiednie wykształcenie, trzeba było czekać jeszcze kilka lat od momentu wejścia w życie postanowienia "o egzaminach”. Remedium na tę sytuację była możliwość, jaką stwarzał artykuł 14 Przepisów dla uczniów Uniwersytetu, stwierdzający, że „sami tylko uczniowie zapisani i matrykułą opatrzeni mogą po ukończonym całkowitym kursie starać się o stopnie akademickie, które dają im prawo tak do podawania się do egzaminów Najwyższej Komisji Egzaminacyjnej na urzędy wyższe [...], jako też starania się o pozwolenie praktycznego wykonywania w kraju nabytych nauk i umiejętności"90. Innym problemem, który wiązał się z przedłużającą się fazą organizacji Królestwa Polskiego, było zaprzestanie działalności przez Najwyższą Komisję Księstwa już w 1813 roku. W rezultacie świeżo ukształtowany system egzaminacyjny $\mathrm{w}$ zakresie rekrutacji na wyższe urzędy został na ponad trzy lata sparaliżowany. Nie wszystkie jednak komisje departamentowe zaprzestały działalności. Nadal swoje funkcje wykonywały komisje w departamentach mazowieckim i poznańskim, a ich orzeczenia podlegały zatwierdzeniu w 1813 roku przez Radę Najwyższą Tymczasową Księstwa Warszawskiego.

Zasady sprawdzania kwalifikacji kandydatów na urzędy, uregulowane postanowieniem z 12 listopada 1816 roku, stanowiły dojrzałą i nieznacznie tylko zmodyfikowaną postać koncepcji krystalizującej się uprzednio w Księstwie Warszawskim na podstawie dekretu z 29 kwietnia 1808 roku. W Europie Środkowo-Wschodniej wdrożenie takiego jak w Królestwie Polskim kompleksowego systemu edukacyjno-rekrutacyjnego, służącego pełnej profesjonalizacji kadr urzędniczych, nie było jeszcze rozpowszechnione ${ }^{91}$. Opierała się ona na

89 „Dziennik Praw Królestwa Polskiego", t. 2, nr 10, s. 242.

90 Zbiór przepisów administracyjnych Królestwa Polskiego. Wydział Oświecenia, t. 1, Warszawa 1868, s. 239.

91 Por. ocenę niskich kwalifikacji zawodowych urzędników administracyjnych w Rosji i trudności związane ze zreformowaniem obowiązującego systemu - M. Raeff, Michael Speransky: Statesman of Imperial Russia, 1772-1832, Haga 1957, s. 60-65. Pisze on m.in. „The need [of competent servants] was equally great in all branches of the state administration, especially in the lower and middle ranks of the bureaucracy" - s. 60; zob. też: idem, The Well-Ordered Police State. Social and Institutional Change through Law in the Germanies and Russia, 1600-1800, New Haven 1983, s. 208-209; T. S. Pearsson, Russian Officialdom in Crisis. Autocracy and Local Self-Government, 1861-1900, Cambridge 1989, s. 2-8. 
podziale urzędów na klasy. W odniesieniu do niego ustalone zostały trzy różne progi wymagań dla kandydatów ubiegających się o posady w służbie publicznej. Niezależnie jednak od klasy o kwalifikacjach kandydata zawsze decydować miały trzy różne kategorie warunków, które musiał on spełnić, aby być zatrudnionym $\mathrm{w}$ administracji - ukończenie właściwej szkoły, legitymowanie się praktyką urzędniczą oraz zaliczenie egzaminów przed komisją egzaminacyjną o urzędniczym charakterze. $Z$ obowiązku zaliczenia egzaminów wyłączone zostały jednak pewne najwyższe stanowiska, przede wszystkim stanowiska o charakterze ministerialnym (członkowie komisji rządowych), które stały się $\mathrm{w}$ ten sposób urzędami czysto politycznymi. Ponadto i praktyka często mogła odbiegać od litery prawa. $\mathrm{W}$ dalszym ciągu zdarzały się przypadki powoływania na urzędy osób, które nie złożyły wymaganych egzaminów. W powstaniu listopadowym praktykę tę próbował ukrócić Rząd Narodowy, wydając 15 czerwca 1831 roku postanowienie nakazujące, „aby nikt bez egzaminu nie był podawany na urzędy". I ono jednak nie okazało się być w pełni skuteczne ${ }^{92}$.

\section{Bibliografia}

\section{Źródła archiwalne}

Archiwum Główne Akt Dawnych w Warszawie, akta I Rady Stanu Królestwa Polskiego, sygn. $67,418$.

Biblioteka im. Czartoryskich w Krakowie, sygn. 5233, 5236.

\section{Źródła publikowane}

„Dziennik Praw Królestwa Polskiego”, t. 2, nr 10.

„Dziennik Praw Księstwa Warszawskiego", t. 1, nr 4, 11; t. 3, nr 32.

Koźmian K., Pamiętniki, t. 2, Wrocław 1972.

Obraz Królestwa Polskiego w okresie konstytucyjnym, t. 1: Raporty Rady Stanu Królestwa Polskiego z działalności rządu w latach 1816-1828, oprac. J. Leskiewiczowa, F. Ramotowska, Warszawa 1984.

Pamiętniki Fryderyka hrabiego Skarbka, oprac. P. Mysłakowski, Warszawa 2009.

Protokoły Rady Stanu Księstwa Warszawskiego, t. 1, cz. 1, oprac. B. Pawłowski, Poznań 1960.

„Zbiór przepisów administracyjnych Królestwa Polskiego. Wydział Oświecenia”, t. 1, Warszawa 1868.

92 W. Rostocki, Postawa polityczna komisarzy obwodowych w 1830-1831 r., [w:] Społeczeństwo Królestwa Polskiego, red. W. Kula, t. 3, Warszawa 1968, s. 11. 


\section{Opracowania}

Bojasiński J., Rządy Tymczasowe w Królestwie Polskim, maj-grudzień 1815, Warszawa 1902.

Chester N., The English Administrative System: 1780-1870, Oxford 1981.

Cichoń P., Korpus urzędniczy w myśli administracyjnej Księstwa Warszawskiego 1807-1815, „Krakowskie Studia z Historii Państwa i Prawa”, red. W. Uruszczak, D. Malec, Kraków 2007.

Cichoń P., Kwalifikacje zawodowe urzędników jako podstawa ksztattowania się systemu biurokratycznego w Księstwie Warszawskim, [w:] Dzieje biurokracji na ziemiach polskich, red. A. Górak, I. Łuć, D. Magier, t. 1, Lublin - Siedlce 2008.

Cichoń P., Rozwój myśli administracyjnej w Księstwie Warszawskim 1807-1815, Warszawa 2006.

Cichon P., Wpływy francuskie w administracji Księstwa Warszawskiego, „Zeszyty Naukowe Uniwersytetu Jagiellońskiego. Prace Historyczne” 2013, nr 140, z. 1.

Gałędek M., Epuracja urzędników w powstaniu listopadowym - przyczynek do dziejów polskiej biurokracji, "Czasopismo Prawno-Historyczne”, artykuł złożony do druku.

Gałędek M., Rekonstrukcja zarządu wojewódzkiego i obwodowego w powstaniu listopadowym, [w:] Przemiany ustrojowe Królestwa Polskiego w latach 1830-1833, red. L. Mażewski, Radzymin 2014.

Gałędek M., Rola administracji w systemie politycznym Królestwa Polskiego do 1830 r., [w:] System polityczny, prawo, konstytucja i ustrój Królestwa Polskiego 1815-1830, red. L. Mażewski, Radzymin 2013.

Gałędek M., Ustawa konstytucyjna Królestwa Polskiego w poglądach księcia Franciszka Ksawerego Druckiego-Lubeckiego, [w:] System polityczny, prawo, konstytucja i ustrój Królestwa Polskiego 1815-1830, red. L. Mażewski, Radzymin 2013.

Izdebski H., Historia administracji, Warszawa 1997.

Izdebski H., Historia administracji a historia biurokracji, „Państwo i Prawo” 1975, z. 5. Izdebski H., Rada Administracyjna Królestwa Polskiego 1815-1830, Warszawa 1978.

Kallas M., Organy administracji terytorialnej w Księstwie Warszawskim, Wrocław 1975.

Krzymkowski M., Status prawny urzędników Księstwa Warszawskiego, Poznań 2004.

Leśnodorski B., Szkoła Prawa i Nauk Administracyjnych w Księstwie Warszawskim, [w:] Studia z dziejów Wydziału Prawa Uniwersytetu Warszawskiego, Warszawa 1963.

Lindenfeld D. F., The Practical Imagination. The German Sciences of States in the Nineteenth Century, Chicago 1997.

Malec J., Wpływy napoleońskie w strukturze administracji ziem polskich w pierwszej połowie XIX wieku, [w:] Studia z dziejów administracji nowożytnej, red. J. Malec, Kraków 2003.

Mycielski M., «Miasto ma mieszkańców, wieś obywateli». Kajetana Koźmiana koncepcje wspólnoty politycznej (do 1830 roku), Wrocław 2004. 
Mycielski M., Rząd Królestwa Polskiego wobec sejmików i zgromadzeń gminnych 1815-1830, Warszawa 2010.

Osterloh K.-H., Joseph von Sonnenfels und die österreichische Reformbewegung im Zeitalter des aufgeklärten Absolutismus: Eine Studie zum Zusammenhang von Kameralwissenschaft und Verwaltungspraxis, „Historische Studien”, nr 409, Lubeka 1970.

Pearsson Th. S., Russian Officialdom in Crisis. Autocracy and Local Self-Government, 1861-1900, Cambridge 1989.

Przygodzki J., Rada Najwyższa Tymczasowa Księstwa Warszawskiego 1813-1815: organizacja i działalność, Wrocław 2002.

Raadschelders J. C. N., Handbook of Administrative History, New Brunswick 1998.

Raeff M., Michael Speransky: Statesman of Imperial Russia, 1772-1832, Haga 1957.

Raeff M., The Well-Ordered Police State. Social and Institutional Change through Law in the Germanies and Russia, 1600-1800, New Haven 1983.

Rostocki W., Postawa polityczna komisarzy obwodowych w 1830-1831 r., [w:] Społeczeństwo Królestwa Polskiego, red. W. Kula, t. 3, Warszawa 1968.

Rowe M., From Reich to State. The Rhineland in the Revolutionary Age, 1780-1830, Cambridge 2003.

Sobociński W., Wydział Prawa i Administracji Uniwersytetu Królewsko-Warszawskiego (1816-1830), [w:] Studia z dziejów Wydziału Prawa Uniwersytetu Warszawskiego, Warszawa 1963.

Stolleis M., Public Law in Germany, 1800-1914, Oxford 2001.

Winiarz A., Organizacja i działalność komisji egzaminacyjnych w Księstwie Warszawskim i Królestwie Polskim (1807-1831), „Przegląd Historyczno-Oświatowy” 1986, nr 4.

Winiarz A., Stanisława Staszica koncepcja organizacji szkolnictwa w teorii i praktyce, „Rozprawy z Dziejów Oświaty" 2006, t. 54.

Witkowski W., Historia administracji w Polsce 1764-1989, Warszawa 2007. 